\title{
A study on the origins of medial circumflex femoral artery
}

\author{
Shiny Vinila B H${ }^{1}$, Suseelamma $\mathrm{D}^{2}$,Sridevi $\mathrm{N} \mathrm{S}^{3}$, Gayatri $\mathrm{N}^{4}$, Sangeeta $\mathrm{M}^{5}$ \\ 1,3,5(Department of Anatomy, Sri Devaraj Urs Medical College, Kolar, Karnataka) \\ ${ }^{2,4}$ (Department of Anatomy, Kamineni Institute of Medical Sciences, Narketpally, AndraPradesh)
}

\begin{abstract}
Medial circumflex femoral artery is a branch of profundafemoris artery. It arises from the posteromedial aspect of the profundafemoris artery in the femoral triangle. It is an important artery in supplying blood to the head and neck of the femur, to the adductor muscles and to fatty tissue in the acetabular fossa. Because of its close relationship with this area there is a high risk of severing the artery after trauma or during operations such as total hip arthroplasty. The material for the present study comprises of 40 lower limbs of adult human cadavers irrespective of their sex. The study was done by dissection method. In 6 extremities (15\%) medial circumflex femoral artery was originated directly from femoral artery. In 7 extremities (17.5\%) a common trunk was observed form medial circumflex femoral and deep external pudendal arteries. Normal study was observed in 27 extremities (67.5\%). These variations of the origins of Medial circumflex femoral artery needs to be taken into account and considered in all the surgical and interventional procedures.
\end{abstract}

Key words: Medial circumflex femoral artery, Profundafemoris artery,

\section{Introduction}

Medial circumflex femoral artery is a branch of profundafemoris artery. It arises from the posteromedial aspect of the profundafemoris artery in the femoral triangle. It is an important artery in supplying blood to the head and neck of the femur, to the adductor muscles and to fatty tissue in the acetabular fossa ${ }^{[1]}$. Gautier E et al, opined that precise knowledge of the anatomy of medial circumflex femoral artery is essential when performing both trochanteric and intertrochanteric osteotomies and is also helpful to avoid iatrogenic vascular necrosis of the head of femur in reconstructive surgery of the hip and fixation of acetabular fractures through the posterior approach ${ }^{[2]}$.

\section{Materials And Methods}

The material for the present study comprises of 40 lower limbs of formalin fixed adult human cadavers irrespective of their sex. The study was done by dissection method.

\section{Observations And Results}

- In 6 extremities (15\%) medial circumflex femoral artery was originated directly from femoral artery.

- In 7 extremities (17.5\%) a common trunk was observed form medial circumflex femoral and deep external pudendal arteries.

- Normal study was observed in 27 extremities (67.5\%)

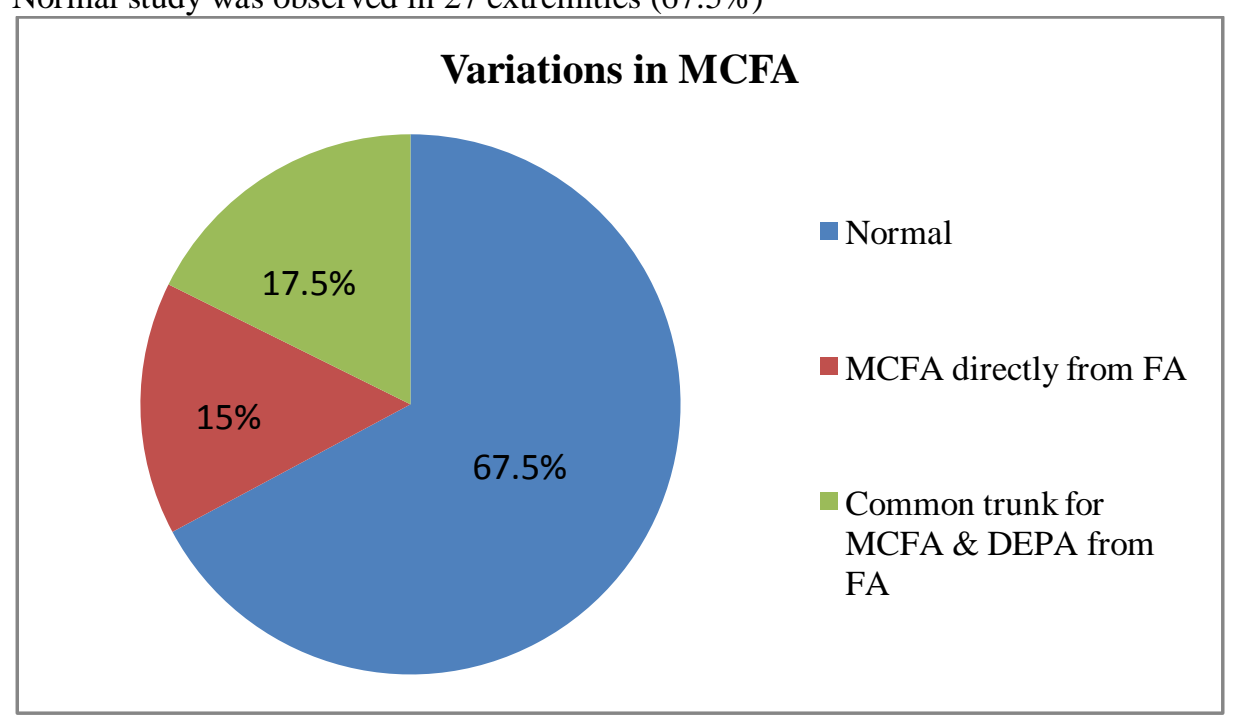


A study on the origins of medial circumflex femoral artery

Table 1: Distance Of Origin Of Medial Circumflex Femoral Artery From The Origin Of ProfundaFemoris Artery.

\begin{tabular}{|c|c|c|}
\hline \multirow{2}{*}{ Range in millimeters } & \multicolumn{2}{|c|}{ Number of origins of MCFA from PFA =27 } \\
\cline { 2 - 3 } & Right side & Left side \\
\hline $10-20$ & 9 & 8 \\
\hline $21-30$ & 3 & 4 \\
\hline $31-40$ & 2 & 1 \\
\hline
\end{tabular}

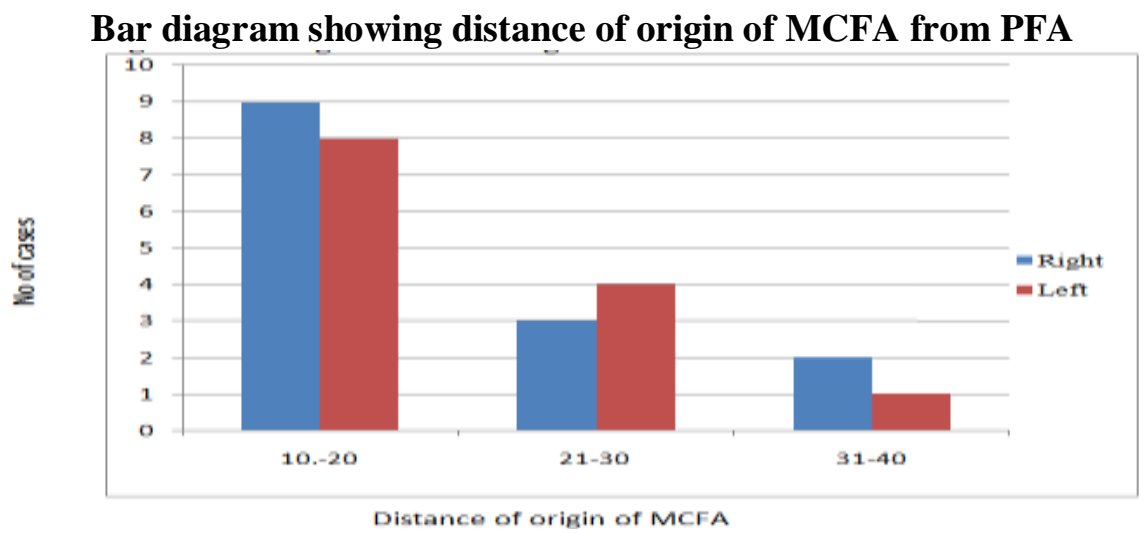

Result: The origin of medial circumflex femoral artery was recorded from the point of origin of profundafemoris artery by using scale in milli meters. The mean $=1.99$ and Standard deviation $=0.68$; so the average distance is $1.99 \pm 0.68 \mathrm{~cm}$.

On right side: Mean $=2.09$ and $\mathrm{SD}=0.68$; so the average distance is $2.09 \pm 0.68 \mathrm{~cm}$. In 9 cases (45\%) it was observed to be 10 to $20 \mathrm{~mm}$.

In 3 cases (15\%) it was 21 to $30 \mathrm{~mm}$, in 2 cases (10\%) it was observed to be 31 to $40 \mathrm{~mm}$. In 6 cases $(30 \%)$ a variation was observed that it was originating directly from femoral artery.

On left side - Mean $=1.88$ and $\mathrm{SD}=0.68$; so the average distance is $1.88 \pm 0.68 \mathrm{~cm}$.In 8 cases $(40 \%)$ it was observed to be 10 to $20 \mathrm{~mm}$.

In 4 cases (20\%) it was 21 to $30 \mathrm{~mm}$, in 1 cases $(5 \%)$ it was observed to be 31 to $40 \mathrm{~mm}$. In 7 cases $(35 \%)$ a variation was observed that it was originating from femoral artery.

Table 2: Distance of origins of MCFA from midpoint of inguinal ligament, from the origin of PFA and variations related to MCFA.

\begin{tabular}{|c|c|c|c|c|c|}
\hline \multirow{2}{*}{$\begin{array}{c}\text { Cadaver } \\
\text { No }\end{array}$} & \multicolumn{2}{|c|}{$\begin{array}{c}\text { From midpoint of } \\
\text { inguinal ligament }(\mathrm{N}=40)\end{array}$} & \multicolumn{2}{|c|}{$\begin{array}{l}\text { From the origin of PFA } \\
(\mathrm{N}=40)\end{array}$} & \multirow[t]{2}{*}{ Variations related to MCFA } \\
\hline & Right & Left & Right & Left & \\
\hline 1 & 6.5 & 5 & 1.5 & 1.0 & No variation \\
\hline 2 & 7.5 & 7.2 & 3.0 & 2.6 & No variation \\
\hline 3 & 5.8 & 5.5 & 3.3 & 2.5 & No variation \\
\hline 4 & 3.5 & 5.5 & - & 1.4 & $\begin{array}{l}\text { Common trunk for MCFA \& DEPA } \\
\text { from FA on right side }\end{array}$ \\
\hline 5 & 3.0 & 3.5 & - & - & $\begin{array}{l}\text { Common trunk for MCFA \& DEPA } \\
\text { from FA on both sides }\end{array}$ \\
\hline 6 & 5.5 & 5.8 & 2.3 & 2.0 & No variation \\
\hline 7 & 1.0 & 1.0 & 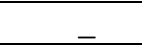 & $\ldots$ & MCFA directly from FA on both side \\
\hline 8 & 4.8 & 5.5 & 1.2 & 1.4 & No variation \\
\hline 9 & 2.0 & 2.5 & - & - & MCFA directly from FA on both side \\
\hline 10 & 5.0 & 5.3 & 1.5 & 1.3 & No variation \\
\hline 11 & 4.8 & 4.5 & 2.0 & 2.3 & No variation \\
\hline 12 & 5.2 & 5.2 & 1.5 & 1.3 & No variation \\
\hline 13 & 5.0 & 2.5 & 2.0 & - & Common trunk for MCFA \& DEPA \\
\hline
\end{tabular}


A study on the origins of medial circumflex femoral artery

\begin{tabular}{|c|c|c|c|c|c|}
\hline & & & & & from FA on left side \\
\hline 14 & 5.6 & 5.4 & 3.2 & 3.1 & No variation \\
\hline 15 & 4.6 & 4.5 & 2.0 & 1.5 & No variation \\
\hline 16 & 2.5 & 2.0 & - & - & $\begin{array}{c}\text { Common trunk for MCFA \& DEPA } \\
\text { from FA on both side }\end{array}$ \\
\hline 17 & 5.0 & 1.5 & 1.8 & - & $\begin{array}{c}\text { Common trunk for MCFA \& DEPA } \\
\text { from FA on left side }\end{array}$ \\
\hline 18 & 5.8 & 5.5 & 2.5 & 2.8 & No variation \\
\hline 19 & 5.6 & 5.4 & 1.5 & 1.3 & No variation \\
\hline 20 & 5.2 & 3.0 & - & - & MCFA directly from FA on both side \\
\hline
\end{tabular}

Result: The average distance from the origin of PFA $=1.99 \pm 0.68 \mathrm{~cm}$. The average distance from midpoint of inguinal ligament $=4.5 \pm 1.62 \mathrm{~cm}$.

\section{Discussion}

The medial circumflex femoral artery on an average was arising in $65 \%$ of cases from profundafemoris artery and in $18.4 \%$ of cases from femoral artery. The result of present study is close to Dixit (2001), which was $62.5 \%$ from profundafemoris artery and $20.63 \%$ directly from femoral artery ${ }^{[3]}$.

Table 3: Comparison of various origins of medial circumflex femoral artery.

\begin{tabular}{|c|c|c|}
\hline Author's Name & Origin from PFA & Origin directly from FA \\
\hline Lipshutz $^{[4]}(1916)(\mathrm{N}=100)$ & $59 \%$ & $36 \%$ \\
\left.\hline${\text { Clarke et. } \mathrm{Al}^{[5]}(1993)(\mathrm{N}=40)}^{[50}\right)^{[3]}(2001)(\mathrm{N}=48)$ & $53 \%$ & $40 \%$ \\
\hline Dixit $^{[6]}(2006)(\mathrm{N}=100)$ & $62.5 \%$ & $20.63 \%$ \\
\hline Tanyeli $^{6]}(20 \%)$ & $15 \%$ \\
\hline MB Samarawickrama $^{[7]}(2009)(\mathrm{N}=26)$ & $62 \%$ & $31 \%$ \\
\hline Present study $(2012)(\mathrm{N}=40)$ & $65 \%$ & $18.4 \%$ \\
\hline
\end{tabular}

In 5\% of cases a common point of origin for profundafemoris artery, medial circumflex femoral and lateral circumflex femoral arteries from the femoral artery. MB Samarawickrama (2009) was observed this pattern in $8 \%$ of cases. This is close to our results. In $11.6 \%$ of cases a common trunk for medial circumflex femoral and deep external pudendal arteries were observed ${ }^{[7]}$.

In the cases in which medial circumflex femoral artery originating directly from femoral artery, the mean distance was $1.99 \pm 0.68 \mathrm{~mm}$, that was smaller than in the cases in which it was originating from profundafemoris artery, that is $4.07 \pm 1.78 \mathrm{~mm}$. due to its high position it can be damaged when the femoral artery is punctured for various cardiac interventional procedures, or it may be damaged while collecting blood in infants from the femoral vein. It is also at risk during exposure of the saphenous vein for ligation at its junction with the femoral vein.Damage to medial circumflex femoral artery leads to avascular necrosis of head of the femur as it is the chief artery for it.

\section{Conclusion}

It also has great importance in plastic surgery operations as the vascular pedicle of grafts such as the transverse upper gracilis (TUG) flap, the super medial thigh flap and the medial circumflex femoral (gracilis) perforator free flap. It is used in selective arteriography in idiopathic ischaemic necrosis of the femoral head to determine the arterial supply of the femoral head. These variations of the origins of Medial circumflex femoral artery needs to be taken into account and considered in all the surgical and interventional procedures.

\section{References}

[1] Susan standring, Pelvic gridle, Gluteal region and Hip joint, Gray's Anatomy, $39^{\text {th }}$ edition, Elsevier, Churchil Livingstone, Spain, 2005; pp.1450-1452.

[2] Gautier E, Ganz K, Krugel N, Gill T, Ganz R, Anatomy of the medial femoral circumflex artery and its surgical implications, J Bone Joint Surg Br,2000, 82 (5): 679 -683.

[3] Dixit, D.P, et al; Variations in the Origin and Course of ProfundaFemoris ; J Anat. Soc. India 2001; 50(1): pp.6-7.

[4] Lipchutz, B.B. Studies on the blood vascular tree, 1,A composite study of the femoral artery. Anatomical Record. 1916:10:pp. 361-70.

[5] Clark, S.M., and Colborn, The medial femoral artery: its clinical anatomy and nomenclature. Clinical Anatomy. G.L. 1993: 6:pp. 94105 .

[6] E.Tayeli et.al, An anatomical study of the origins of medial circumflex femoral artery in Turkish population, Folia Morphologica, These variations of the origins of Medial circumflex femoral artery needs to be taken into account and considered in all the surgical and interventional procedures.2006; 65, No. 3: pp.209-212

[7] MB Samarawickrama ,BGNanayakkara ,KWR Wimalagunarathna ,DGNishantha, UBWalawag; Branching pattern of the femoral artery at the femoral triangle: a cadaver study e; Galle Medical Journal, September 2009; Vol 14: No. 1, pp. 31-34. 
Illustration: Common trunk for MCFA and deep external pudendal artery

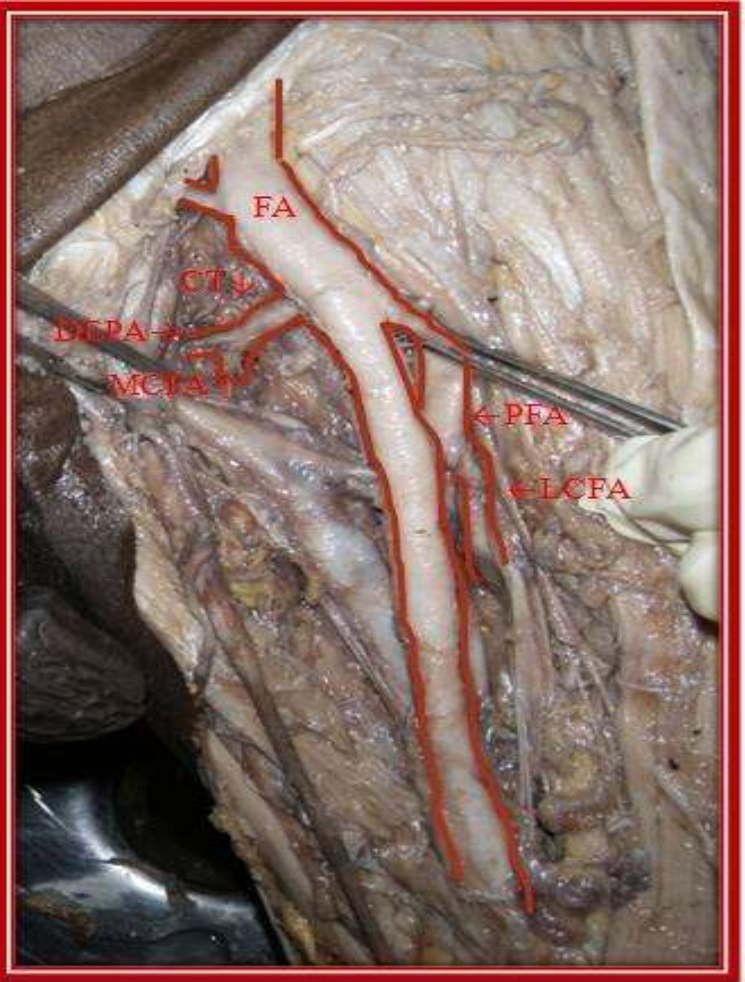

FA - Femoral artery, CT - Common trunk

DEPA - Deep external pudendal artery

MCFA - Medial circumflex femoral artery

PFA - Profundafemoris artery

LCFA - Lateralcircumflex femoral artery 